\title{
Heidegger and the Narrativity Debate
}

\section{Introduction}

Over recent years much ink has been spilt discussing the relation of Heidegger to Narrativity. One might wonder, indeed, whether anything more could be said on the matter. This article will venture, at the risk, perhaps, of immodesty that it can. In my opinion, not only is it possible to contribute to this debate, it would be remiss not to do so, for the debate thus far has merely entrenched two opposing and apparently irreconcilable factions within the Heidegger literature - both claiming equal textual legitimacy. My purpose here is to offer, in response, an alternative to these two antithetical positions. As we shall see, the key to resolving this dispute lies in the concept of historicality - the view that man is "historical" in his being - and the emphasis one places on it when interpreting Being and Time. For it is over this issue that the two camps, whom we are about to meet, are most deeply divided. To pose the principal question at stake, then: is it correct to say that historicality cannot be fully explicated without recourse to the notion of authenticity, and doesn't authentic historicality presuppose, in turn, the concept of Narrativity? Or, is there some alternative way of accounting for historicality that does not entail the view that authentic human self-experience should be narrative in form?

Certainly, there are good reasons for believing Heidegger does indeed embrace the notion of narrativity. Heidegger's passionate protestations against the self-estrangement of Dasein under the "dictatorship" of das Man, which conspires to strip it of the kind of resolve necessary for having a genuine 'destiny' (Schicksal), ${ }^{1}$ are well known. Equally, Heidegger presents himself, at least rhetorically in Being and Time, as an eloquent advocate for the "authentic life" - and for some, at least, that entails a resolute commitment, on the part of authentic Dasein, to a life-defining project that matters to it precisely because it takes into account the finitude of existence. Charles Taylor, for one, reads into the modalities of authenticity and inauthenticity a distinction that he associates with what he terms "strong evaluators" and "simple weighers". A strong evaluator is someone capable of acting upon what matters in the long-run, in contrast to the simple weigher who acts upon immediate wants and desires. And strong evaluation, he argues, is "essential to our notion of the self" ${ }^{2}$ because it requires "a reflection about the self, its most fundamental issues... what is at stake is the definition of

\footnotetext{
${ }^{1}$ Heidegger (1927, p. 384.436).

${ }^{2}$ Taylor (1976, p. 282).
} 
those inchoate evaluations which are sensed to be essential to our identity". ${ }^{3}$ In a similar vein, Charles Guignon has proposed the "authentic stance toward life makes us face up to the fact that to the extent that we are building our own lives in all we do, we are 'answerable' for the choices we make". 4

And yet according to others there are grounds for believing such a view deeply inconsistent with Being and Time, given the emphasis Heidegger places there on the existentiality of Dasein - the "being-ahead-of-itself" of care. For these commentators, Heidegger's existential analytic reveals Dasein to be both intrinsically unattainable, insofar as it is a nullity to itself, and ultimately unattainable, insofar as it exists as being-towards-death - forcing us to acknowledge that a rather unsettling distinguishing feature of Dasein's kind of existence is its fundamental incapacity to ever really coincide with any present interpretation of itself. Thus Taylor Carman rejects what he calls the "Expressivist" tradition, which "relies essentially on a normative ideal of completion, wholeness, totality, unity". In short, what he rejects is any talk of authentic historicality and, thus, of Dasein's capacity for "self-constancy" as imposing upon it "a normative ideal of integrated selfhood, of integrity understood as being oneself, or being true to oneself." 5

Given the peculiar exegetic challenge this dispute undeniably presents, this article will have to work through three associated tasks in order to better understanding the paradox arising from the very locution "authentic historicality". First, I will interrogate the Narrativity Thesis, specifically as it pertains to the issue of personal identity and its normative commitments. Second, I will assess, in view of this, the extent to which Narrativity is applicable to Being and Time. And since there are indeed deep and intractable problems associated with the term, thirdly, I will propose an alternative to Narrativity, which will nevertheless enable us to preserve some of its key insights regarding the nature of self-constituting existence. Finally, in answering the particular question - is Heidegger a narrativist? - I hope to challenge these two prominent readings of Heidegger, one narrative, the other antinarrative, and, in doing so, suggest an alternative exegetic model for interpreting Being and Time, conceived, not in terms of Narrativity, but rather, in terms of the broader hermeneutic condition of "narratability", as I shall describe it.

\footnotetext{
${ }^{3}$ Ibid., p. 299.

${ }^{4}$ Guignon (1993, p. 232).

${ }^{5}$ Carman (2003, p. 266).
} 


\section{Narrativity and its Commitments}

Narrativity responds to a peculiar problem identified with mainstream theories of personal identity by its critics. Viewed generally, personal identity theorists can be said to ask the question of what constitutes a sufficient and necessary condition for the continuation of the self through time: what makes a person at $t^{1}$ and at $t^{2}$ the same person? Within the Anglo-American tradition this comes down to what one such critic, Marya Schechtman, calls the "reidentification question". Reidentification theorists typically apply (to the problematic of personal identity) the more general metaphysical question of how a single entity - for instance, "Theseus's Ship" - can be said to persist through change. Though we must pass over the rich nuances of this debate, one feature of the traditional approach to reidentification is of particular relevance in helping to understand the force of the narrative alternative. If reidentification theories see themselves as accounting for personal identity on explicitly metaphysical grounds - that is, according to the puzzle temporal extension seems to pose for establishing the identity of an entity whose parts must, according to this perspective, be viewed as temporally distinct - it is precisely because of the third-personal perspective the reidentification theorist adopts in her approach to the phenomenon. In other words, the reidentification puzzle is itself generated by this external approach taken to the issue of identity. The reidentification question, rather crudely stated, asks: how can two discrete temporal objects really be identical? While there are numerous ways of answering this puzzle within reidentification most of the disputants nevertheless accept that the key to resolving the dilemma lies in establishing appropriate causal connections between "person-stages" or person "time-slices". What Schechtman's analysis suggests, however, is that all reidentification theories are ultimately inadequate when confronted with the kinds of question that matters most to us in our everyday concern for personal identity. ${ }^{6}$ Adopting a third-personal and metaphysical approach, not only are reidentification theorists simply unable to answer to our best commonsense intuitions about what it is to be a self; specifically, for Schechtman, they all miss the crucial link any theory must establish between our practical interests and the role such interests play in the constitution of the identity of persons. In fact, what matters most about personal identity, viewed in commonsense terms, is, as Kim Atkins has recently claimed, "one's continued existence as the same

\footnotetext{
${ }^{6}$ She cites Lewis, Perry, Parfit, and Shoemaker as providing different theories of reidentification.
} 
experiential subject". ${ }^{7}$ It is to this intuition, above all others, that identity theories are (on her view at least) ultimately accountable. To give a brief sense of the problems such theories confront, Atkins explains:

If my survival consists in the on-going existence of attributes exemplified in me, rather than in me being the numerically identical subject of my experiences, then it is not at all clear why I should, for example, dread what will happen to a future person in whom those attributes are exemplified, just as I would for myself. After all, I will not feel her pain - I cannot even anticipate her pain since I can only anticipate my own. Similarly, in this situation, the notions of moral responsibility and compensation break down: it only makes sense to punish or reward me for my efforts, not someone who happens to be more like me than anyone else. ${ }^{8}$

Reidentification theories simply fail to establish in any sufficiently robust sense the appropriate psychological transitions capable of ensuring continuity between a person's past, present and future. Therefore, rather than searching in vain for an extrinsic connection, Schechtman advocates an internal response to the problem of identity; for it is only when identity is viewed experientially that we can begin to make any headway into the essential connection between the constitution of the self and what Schechtman identifies as four primary practical features that any theory of personal identity must be capable of accounting for: personal survival, moral responsibility, self-interested concern, and what she terms compensation (for injuries sustained during, or benefits accruing to, any present action I might undertake).

What counts, therefore, according to the views of Schechtman and Atkins, inter alia, are not metaphysical facts about psychological or bodily continuation between noncontinuous person-stages. Nor is it therefore a question of establishing a criterion capable of reidentifying a person as the same on merely logical grounds. Rather, what counts in questions of personal identity is what Marya Schechtman refers to as the characterisation question - "the question of which beliefs, values, desires, and other psychological features make someone the person she is". ${ }^{9}$

\footnotetext{
${ }^{7}$ Atkins (2005, p. 360).

${ }^{8}$ Ibid, p. 361.

${ }^{9}$ Schechtman (1995, p. 2).
} 
In appealing to character, Schechtman directly appeals to the experience we have of ourselves as self-narrating agents - as characters playing the role of the central dramatis persona of our own stories. The characterisation question is not only an internal question, however, in the formal sense intended by Schechtman when she writes "The narrative theory seems possibly better placed to capture the idea that acceptable changes must be internally generated developments" ${ }^{10}$ Insofar as it is meant to explicate the connection between the self and the four practical features, it also has an essentially normative design.

In other words, in asking what characteristics I take to be essential to who I understand myself to be, characterisation also challenges me to render explicit whatever inchoative values, beliefs, and attitudes I take to be essential to my sense of self. It is only by making whatever inner characteristics I possess clear to myself that I can then get clear about myself; and only in this way, as Charles Taylor describes it (above), do I become a strong evaluator. Strong evaluation insists on my necessarily taking up the kind of critical, self-reflective stance that self-explicitation patently requires. On the other hand, self-explicitation inevitably requires narrative self-organisation. Firstly, because a reflective capacity to form reasons for my practical conduct involves an acknowledgement that $I$ am responsible for my past and present actions and will be responsible for my future actions; and, secondly, that any such capacity must therefore, at least if they are to be truly my reasons, be "grounded in [the] core attributes of ourselves which we value". ${ }^{11}$ As Atkins succinctly expresses it, "narrative identity and moral life go hand in glove in a reflective conception of personhood". ${ }^{12}$ Indeed, it is precisely because its concerns are ultimately normative that the characterisation view, in seeking an answer to the problem of identity, necessarily turns to Narrativity. Again, Schechtman: "Without the sense of oneself as a persisting individual whose actions should cohere with one's beliefs, values, and desires... and whose current actions have implications for the future, one does not have the capacity for moral responsibility". ${ }^{13}$

Here, we can begin to appreciate just how strong the commitments of the Narrativity Thesis really are. In a word, Narrativity combines both substantive and normative conceptions together to yield a criterion for establishing "what-it-is-to-be-a-person"; and note that criterion requires us to

\footnotetext{
${ }^{10}$ Schechtman (2005, p. 244).

${ }^{11}$ Atkins (2005, p. 363).

12 Ibid., p. 363.

${ }^{13}$ Schechtman (1995, p. 159).
} 
conceive of persons in indisputably ethico-juridical terms. Specifically, the Narrativity criterion commits us to two basic conditions: (1) to be a self, a person, a "who", requires that one has a Narrative self-conception; the stronger one's narrative self-conception, the stronger one's sense of self. Call this NR, the Narrativity Requirement. NR states: to be a person requires one has a coherent narrative self-conception. This view receives the wholesale endorsement of Schechtman, who asserts,

The narrative self-constitution view... demands that a person's self-conception take the form of a traditional linear narrative because it is this kind of self-conception which underlies the attitudes and practices that define the life of a person. ${ }^{14}$

While Schechtman concedes that such a self-conception need not be overtly conscious to the agent, it is ultimately necessary that it becomes so - which is precisely the point at which the Narrativity Requirement imposes upon the self-constitution view what we might refer to as high-end and in fact normative constraints. Thus, the more explicitly focussed, singular and attainment-directed one's self-conception, the more coherent, effective and accomplished one will be as a person. But, accordingly, in addition to NR, we find implicit in this requirement the normative idea that Narrativity should indeed be made explicit. Call this NS, the Normative Stipulation (2). NS states: in order to preserve the autonomy of the self, one ought to make one's narrative self-conception fully explicit for oneself. This is because only someone with a strongly narrative sense of self could really embrace the essential connection any self has with the four features and thus see themselves in the capacity of moral agents, equipped to act on the basis of reasons, that is to say, as strong evaluators.

How applicable, though, is the Narrativity Thesis to Heidegger? Should we really sign him up to these commitments, specifically to NR and NS? In order to make progress with these questions, first, I want to draw together two diametrically opposed positions within Heidegger interpretation and, second, bring to the fore the controversy engendered by Narrativity that sweeps Heidegger scholarship along in its wake.

\footnotetext{
${ }^{14}$ Schechtman (1995, p. 105).
} 


\section{Heidegger and the Narrative Controversy}

Seen in terms of Heidegger, the question appears rather straightforward: is Dasein narrative or nonnarrative? In other words, the question comes down, prima facie, to a decision over which of the two interpretations of Being and Time already indicated in the introduction is right.

Let me run through in more detail the key distinguishing features of these two approaches to Being and Time, presenting the case for narrativism first.

The commitments, roughly put, are as follows. Heidegger has a view about personal identity as it is usually understood. That is, Heidegger has an affirmative answer to the question of whether or not the self should be viewed as a diachronically extended entity, capable of being unified as an autobiographic whole. Correlative to this, he sees the possible diachronic unity of the self as explaining certain core features about human existence - for instance, how it is we can take responsibility for the lives we lead, or alternately, lose touch with ourselves. This view therefore commits him to the idea that to be a self - at least to be itself authentically - Dasein must be viewed as being narrative in form. So, for example, in his Sources of the Self, Charles Taylor sees a "basic degree of narrative understanding" as intrinsic to "the inescapable temporal structure of being-in-the-world". ${ }^{15}$ But he also concludes that the temporality of everyday existence makes the Narrativity Thesis inevitable: "My self-understanding necessarily has temporal depth and incorporates narrative". ${ }^{16}$ This is supplemented with the insight: "we cannot but strive to give our lives meaning or substance, and... this means that we understand ourselves inescapably in narrative". ${ }^{17}$ This means that "as I project my life forward and endorse the existing direction or give it a new one, I project a future story, not just a state of the momentary future but a bent for my whole life to come". ${ }^{18}$

The most robust case for Heidegger as a narrativist is made by Charles Guignon, and in particular with his glosses on the notions of authenticity and historicality. In fact, historicality, on his account, serves as a kind of term of mediation between two otherwise quite distinct notions, those of temporality and Narrativity. But it is notable that what makes such mediation plausible - and it is this which serves to bring Heidegger firmly into the orbit of the Narrativity Thesis - is the figure of

\footnotetext{
${ }^{15}$ Taylor (2002, p. 47).

${ }^{16}$ Ibid., 50 my emphasis.

${ }^{17}$ Ibid., 51.

${ }^{18}$ Ibid., 48.
} 
Wilhelm Dilthey: “The temporal axis of Dasein's Being plays a role similar to Dilthey’s 'structure': it provides the formal scaffolding in which any concrete life in particular is lived". ${ }^{19}$ It is due to this structural proximity that Guignon is able to venture the de facto collapse of the positions of Dilthey and Heidegger: "The hermeneutic structure of life may be made clearer by an analogy with the writing of autobiography... Autobiography may be thought of as an explicit form of what we all do all the time: in a sense, we are all composing our autobiographies as we live". ${ }^{20}$ In this way, as with the previous examples, Heideggerian authenticity is implicated firmly in the normative commitments of Narrativity in that, in order to accomplish the authentic life, the self requires some project through which it can pro-ject its ownmost capacity for being-a-whole; thus Heideggerian "resolve" implies for this reading a narrative resolution. It is thus that Guignon interprets Heidegger's concept of authenticity in terms of NR and NS: "In contrast to the dispersal and endless 'making-present' of everydayness, such a life is authentically futural to the extent that it clear-sightedly faces up to the inevitable truth of its own finitude and lives each moment as an integral component of the overall story it is shaping in its actions". ${ }^{21}$

The evidence cited for the narrative interpretation of Heidegger is the thesis of authentic historicality, and specifically, the question of self-constancy. ${ }^{22}$ As Heidegger expresses it: "[The]

\footnotetext{
${ }^{19}$ Guignon (1983, p. 92).

${ }^{20}$ Ibid., p. 93.

${ }^{21}$ Guignon, (2000, p. 89). I take Guignon to be an exemplary case of narrative Heidegger, but there are
} others of course. For instance, David Carr also reads Heidegger as narrative in Time, Narrative, and History: "what seems decisive to Heidegger in the concept of authenticity is really the problem of authorship. He takes up Dilthey's notion of autobiographical Besinnung on the whole of one's life, though in more dramatic terms... what counts for Heidegger, it seems, is whether I am composing [my life-story] myself or drifting along according to a script of indeterminate or anyonymous authorship" $p$ 83; see also, p. 111. And, elsewhere, Theodore Kisiel writes: "We cannot in principle afford to dismiss the biographical element as fortuitous and so irrelevant, contrary to the pronouncements of would-be purist Heideggerians. For Heidegger himself tells us... that his thought stems from his life and that one can therefore not divorce the ontological (his philosophy) from the ontic (his biography)" (Kisiel, 1995, p. 79).

${ }^{22}$ In fact: “die Frage nach der Ständigkeit des Selbst” SZ p. 317. 
question of the constancy of the Self [is] defined as the 'who' of Dasein. Self constancy is a way of Being of Dasein"23; which Guignon interprets: "One's resolute stance in relation to death guarantees the continuity and constancy of a life-course". ${ }^{24}$ On these grounds, Guignon concludes, "in taking a stand on its own life, Dasein takes over some range of possibilities as definitive of its identity - some set of personality traits, life-styles, roles, or attitudes - and exists as 'being-toward' the realization of a final configuration of possibilities for its life overall". ${ }^{25}$

In light of this description, let me call the narrativist reading, the "final configuration view" against which we might now pit the case for a non-narrativist reading of Being and Time.

The commitments of this view are as follows. Heidegger's ontology prohibits him from endorsing a narrativist reading of Dasein, if we take the latter to mean that Dasein is an entity that is somehow attainable "in time". Ecstatic temporality prohibits the traditional ontic characterisation of the person, and it is precisely this which the narrative view appears to tacitly sanction. More specifically yet, Heidegger's existentialism fundamentally undermines a narrativist reading: in beingtowards-death we should recognise that no practical project can answer the question of who Dasein is. Ontologically viewed, Dasein is fundamentally undecidable in its being; its who remains "at issue" period. Taylor Carman tells us for example that "what distinguishes Heidegger from the expressivist tradition... is his radical rejection of any conception of Dasein as a finished or in principle finished self, an integrated whole, a complete occurrent entity”. ${ }^{26}$

The evidence for this view is complex, but essentially comes down to an entailment of Heidegger's claim that "There belongs to Dasein, as long as it is, a 'not-yet' which it will be". ${ }^{27}$ On this view, Dasein is defined (a) by its being a nullity and (b) by its being essentially an open-ended

\footnotetext{
${ }^{23}$ Heidegger (1962, p. 427).

${ }^{24}$ Guignon (1992, p. 135).

${ }^{25}$ Guignon (1993, p. 225).

${ }^{26}$ Carman (2003, p. 266).
}

${ }^{27}$ Heidegger (1962, p. 286). That is also why Heidegger speaks, in rather more hyperbolic terms, of the "abyss of being a self" (MFL, 182). It is of the essence of the self that it is null; but note, this does not mean that Heidegger thinks, as Daniel Dennett does, that the self is a "wonderful fictional object" (Dennett, 1992, p. 104) - one that does not really exist. He means that nullity pervades this mode of existence through and through. 
possibility. This means that in its very being, Dasein is factically unattainable since no factical attainment can supplement the nullity that it is, nor subdue the possibility that defines it. It is worth mentioning, here, a passing remark Heidegger makes at one point in Being and Time, which seems to lend credit to the critics of the final configuration view precisely because it explicitly references it: 'Even when it still exists but has nothing more 'before it' and has 'settled its account', [Dasein's] Being is still determined by the 'ahead of itself"'. ${ }^{28}$ Consequently, in contrast to the views of the "final configurativist", I will designate the anti-narrative interpretation the "unattainability" view. The unattainability view is perhaps most succinctly summarised by Hubert Dreyfus when he reflects on the consequences for Dasein of authenticity, which he says manifests "my understanding that no specific project can fulfil me or give my life meaning", ${ }^{29}$ It should be noted, parenthetically, that the key players here - Dreyfus, Carman, and William Blattner - each either attempts to reject, subdue, or, in the case of Carman, simply ignore altogether, the thesis of historicality.

How, then, given the stark picture outlined here, can we hope to steer a middle course between the Scylla of narrative and Charybdis of anti-narrative interpretations of Being and Time? In fact, it is not so much a matter of reconciling these two rather incompatible readings, but rather, of reconciling Heidegger's comments about historicality (and specifically authentic historicality) with his undeniable existential commitments. I take this to be a crucial task not least because both final configuration and unattainability views have good exegetic reasons for their conclusions, and that means Being and Time appears to end up as rather contradictory. ${ }^{30}$

Some preliminary observations, regarding both of these positions, will help orientate us here.

For Taylor Carman the final configuration view misconstrues the nature of the "whole" that Heidegger is looking for when he asks how one can arrive at an adequate - that is, "existentialontological" - interpretation of the structural totality of Dasein. He writes,

\footnotetext{
${ }^{28}$ Heidegger (1962, p. 279).

${ }^{29}$ Dreyfus (2001, pp. 321-323).

${ }^{30}$ Of course the reason for this may just be that Heidegger's argument really is paralogistic. However, this is not something we are in a position to decide until we have at least tried to make sense of this paradox, and done so by attempting to carve out a plausible alternative to the two disputed positions.
} 
Dasein can achieve no kind of real unity over and beyond its formal unity as a concrete particular, nor therefore can it literally be broken into fragments. Neither can it be made whole by any of its commitments or projects, nor is it ever merely part of some larger whole (...) it cannot enjoy any kind of integration beyond its own resolute forerunning into death. ${ }^{31}$

I agree with Carman, of course, that Dasein cannot achieve any "real" unity. It is, as Heidegger repeatedly insists, no occurrent thing. However, several points of ambiguity result from Carman's characterisation. This becomes particularly acute towards the end of his account where he argues that we need to supplement Heidegger's analysis in such a way as to provide for the "possibility... of a more fully integrated concept of persons".32 There is a discrepancy, then, in Carman's view between what he perceives to be the possibility of authentic self experience, which requires a radically "asymmetrical" conception of the self - and the "interpersonal sensitive understanding of myself"33 that we might wish for but which Heidegger's account of authenticity seems to preclude. Heidegger's hostility toward modern conceptions of subjectivity, in short, leave Dasein stranded on the isolated shores of the solus ipse through the "ontologically perplexing asymmetry of the self'. ${ }^{34}$

There are several objections that could, I think, be made against this interpretation. First, in an effort to distance himself from the expressivist reading, Carman imposes far too formal a requirement on the achievement of authenticity with the consequence that the asymmetry of the self is indeed conceived in a wholly radical way. It is far from clear, however, that this does Heidegger's intentions justice. Indeed, the unattainability perspective, in tending towards a wholly formal conception of Dasein, is led to overlook the possibilities of narrativity, which are at the very least implied in Heidegger's account of resolute forerunning. Moreover, as Carman's own locutions frequently suggest, it is far from clear how one could evade the language of narrativity, even given the limited horizons imposed by unattainability. To be sure, Carman says that Dasein can attain "formal unity" as a concrete particular. But what exactly does this mean? Carman suggests that instead of

\footnotetext{
${ }^{31}$ Carman (2003, p. 300 my italic).

32 Ibid., p. 312.

${ }^{33}$ Ibid.

${ }^{34}$ Ibid, p. 311.
} 
advocating the kind of biographical "wholeness", as conceived by the expressivist tradition, Heidegger should be understood instead as arguing for a distinct kind of experience in which the "whole of Dasein" is grasped with respect to its fundamental impossibility or finitude. Hence Carman writes:

Heidegger's response to this problem is in effect to change the subject in a subtle but profound way by replacing the very idea of human existence understood as a unified whole with a concrete internal interpretation of Dasein as owning up wholly - that is, wholeheartedly - to itself in its existence. ${ }^{35}$

But again, it is hard to know what the argument for wholeheartedness amounts to, or why it should necessarily preclude the possibility of narrativity. Certainly, Carman is right to say that authenticity requires that "Dasein stands [in relation] to itself in the bare recognition of the that of its existence". ${ }^{36}$ What Carman means, I think, can best be expressed through an example - although I doubt he would appreciate this way of putting it. Say I am faced with a decision of the kind Sartre describes in Existentialism and Humanism ${ }^{37}$ in which I am presented with two equally compelling but competing demands, each as good or as bad as the other - how am I to choose between them? For normative accounts of subjectivity, such as Kant's, the subject comes fully equipped with its own evaluative resources: the subject just is the ultimate foundation for effective self-legislation, which is what Kant means by autonomy. But Heidegger's point is that Dasein has no such self-awarded "power of attorney", so to speak, to which it can appeal in order to reach a rational decision. For Heidegger, as for Sartre, to decide is always to recognise the nullity of one's existence; and thus to decide in the full realisation of this nullity is to allow oneself to be thrown "resolutely" back upon one's situation, understanding both the necessity of the choice that one has to make but also the radical contingency of one's commitments. Authenticity does not tell me how to decide, then; it only says that I must do so.

\footnotetext{
${ }^{35}$ Carman (2003, p. 276).

${ }^{36}$ Ibid., 307.

${ }^{37}$ Sartre describes the choice confronted by a pupil of his during the war who had to decide "between going to England to join the Free French Forces or of staying near his [ailing] mother and helping her to live" Sartre, 2008, 39. Sartre's rather unhelpful reply: "You are free, therefore choose - that is to say, invent” (Ibid., p43).
} 
But Heidegger's story, in my view, although it appears to embrace a notion of radical isolation from the "others" by making Dasein face up to its own null existence - for instance, in the call of conscience by no means involves confronting a total and abject deprivation of all content which would make any choice factically meaningless; nor does it involve a radical separation from others, as Carman suggests (on the contrary, it opens up the possibility of authentic solicitous relations with them.) And, in fact, Heidegger explicitly asserts: "What the call discloses is unequivocal, even though it may undergo a different interpretation in the individual Dasein in accordance with its own possibilities of understanding." 38

When Heidegger says, then, that Dasein must "bring itself back" from its lostness in das Man by "“making-up' for not choosing" ${ }^{39}$, he means two things: first, that Dasein chooses to choose, that is, it becomes resolute before this choice; and second, that in choosing, Dasein decides for itself on an "ability-to-be" in the full recognition that who it is depends on the singularity of this choice. Here, contrary to what Carman suggests, it seems Heidegger is borrowing far more than mere rhetoric from Kierkegaard: "Freedom [for its existentiell possibilities] is only in the choice of one possibility - that is, in tolerating one's not having chosen the others and one's not being able to choose them". ${ }^{40}$ Rather than "devoting" itself to its "world" as disclosed in everyday forgetfulness, Dasein now understands itself from its ownmost possibility of existence as exemplified by a singular choice. Projecting onto its chosen "for-the-sake-of-which", says Heidegger, Dasein "exists as itself" ${ }^{41}$ Dasein may not be "attainable" in a substantive sense, then; but there is nothing to stop it from attaining a sense of completion through the realisation of a project upon which it has authentically resolved, and with which it now identifies itself. Equally, of course, Dasein may very well attain a sense of wholeness, completeness and unity in wholeheartedly committing itself to a project, regardless of whether that project were ever to be finished. Now, no doubt there are reasons to be sceptical of this reading, my point here however is that there is nothing in Carman's notion of wholeheartedness per se that prevents this solution. In one sense, then, Carman's own position is rather too circumspect: but in another

\footnotetext{
${ }^{38}$ Heidegger (1962, p. 318, my italic).

${ }^{39}$ Ibid, p. 313.

${ }^{40}$ Ibid., 331.

${ }^{41}$ Ibid., p. 186/ see also p. 344.
} 
sense, and indeed precisely because it attempts to overcome the "pessimism" of the Dreyfian version of the unttainability thesis, it cannot help but slip back into the language of final configuration:

Even if he is right to refuse to assimilate first-person self-understanding to any second- or third-person conception of intraworldly selves, then, his account remains unsatisfying inasmuch as it tells us nothing about the hermeneutic condition of bringing the two perspectives together in an overarching interpretation of human beings as selves. ${ }^{42}$

Now, regarding the final configuration view, I think Guignon's claim that the "authentic stance towards life", which entails our adopting the kind of reflective stance intended by the ethicojuridical conception of the self looks misguided when applied to Heidegger. As we have already suggested, Heidegger rejects the traditional concept of the person as ontic, and this, in my opinion, allows the unattainability view to trump final configuration. We might call this the "exegetic" objection. So, final configurativists such as Guignon go too far when they interpret, as Guignon does, Heidegger's motto "Become what you are" and "[Dasein] is what it becomes"43 to mean "Dasein has been formally characterised as an entity that cares about its life and projects some plan for its life as a whole." ${ }^{44}$ In fact, Heidegger explicitly rejects this kind of interpretation when he says, "Projecting has nothing to do with comporting towards a plan that has been thought out, and in accordance with which Dasein arranges its Being". ${ }^{45}$ We would be prudent, if this is right, to desist from interpreting the phrase "become what you are" to equate to "become the person you are" - become, that is, your narrative self-conception. Still, there are two aspects of Narrativity that I think are right. Firstly, any talk of my identity is rendered unintelligible when it fails to respect the perspective from which it is enunciated. Because the question of identity is itself articulated by ourselves to ourselves, any answer to the question of what a self is must remain, so to speak, internal to the phenomenon. To be specific, it must be answerable to the experience I have of myself. "What-it-is-to-be-a-self", indeed, requires a phenomenological approach, and that rules out the kind of external perspective that generates the

\footnotetext{
${ }^{42}$ Carman (2003, pp. 268-9, my italic).

${ }^{43}$ Heidegger (1962, p. 185).

${ }^{44}$ Guignon (1983, p. 96, my emphasis).

${ }^{45}$ Heidegger (1962, p. 185).
} 
reidentification question. More significantly, the Narrative approach to the self is right to insist on selfconstitution as a distinguishing feature of self-experience. Self-experience is "internally generated"which is not to say that selves are internal phenomena. It means, rather, that by definition a certain kind of autonomy belongs to the being of the self. We might express this autonomy in the following way: as opposed to entities such as stones, buildings, or even higher order primates, such as Chimpanzees and Apes, to exist as a self means to exist as a self-interpreter. To exist as a selfinterpreter is to exist as worldly and not as something "worldless", as Heidegger puts it at one point. ${ }^{46}$ Still, it is far from clear that existing as a self-interpreter needs to involve anything like the sense of wholeness that the Narrativity Thesis imposes, through NR and NS. While it is unquestionably true to say Heidegger thinks it a good thing that we get clear about ourselves (if by that we mean authenticity is a preferable state), it remains far from obvious that the task of self-explicitation, as conceived by Heidegger, involves explicitating the story of myself - getting clear about my narrative self-conception. In order to see why this is indeed inappropriate, however, we need to attend more carefully to the phenomenon Heidegger has in mind in speaking of the self. Here, however, we confront a problem, at least if we want to insist on the connection between selfhood and historizing. For if we are right in saying that the Narrativity Thesis provides an inappropriate way of thinking about historizing, we still need to make sense of a rather paradoxical notion: that of a non-narrative interpretation of historicality. Now, since the anti-narrativist interpreters of Heidegger regrettably offer only negative assessments of historizing, I want to turn instead to a rather unlikely, even provocative, source for help - in fact, to the recent work on Narrativity of Galen Strawson.

There are two reasons for doing so, however heterodox this may appear. First, Strawson offers a useful alternative to both the reidentification and narrativist perspectives on the self, advocating what he calls the "episodic view", where the self is taken to be something that exists independently of any narrative self-ascriptions and of any psychological connection to its putative past and future states. Secondly, Strawson himself reads Heidegger as a narrativist ${ }^{47}$ so by going against the grain of his reading, we can show that (a) the structure of Dasein is not incompatible with a non-

\footnotetext{
${ }^{46}$ See Heidegger's 1929/30 lecture course, The Fundamental Concepts of Metaphysics. See in particular, Heidegger's three theses in section 42, chapter two: “[1.] the stone (material object) is worldless; [2.] the animal is poor in world; [3.] man is world-forming" (Heidegger, 1929/30, p. 177).

${ }^{47}$ See Strawson (2005a, p.64).
} 
narrative notion of historizing; but, correlative to this, (b) the non-narrative view cannot entirely evade the kinds of question raised by Narrativity. In fact, to be rendered coherent, the episodic description of the self will be shown to require some level of narrativity, however minimal. It is at this point that I will be able to present my alternative to Narrativity.

\section{Toward a Non-Narrative Account of Historicality}

Can we, then, conceive of Dasein in episodic terms, however broadly construed, and what would it mean for the final configuration view if we could?

Let us consider the phenomenology.

I take this to be relatively uncontroversial: day-to-day commitments do not invoke anything like the "whole meaning of my life". Day-to-day involvements are not high-end Narrativity at all but rather more mundane and inconsequential. Take for example my going to the bank in order to deposit a cheque. To be sure this involves a perfectly intelligible set of actions, for instance, selecting a time of day when the bank won't be busy, filling in the paying-in slip, negotiating with the cashier. By the same token, to say that such an action is intelligible is also to say that the reason for performing it is already perfectly coherent to me: I understand the meaning of the "in order to" - the task at hand because I have already projected the reason for taking this action ahead of my actually doing so. In Heidegger's terms I project a for-the-sake-of-which - say in this case "for the sake of paying my bills on time" according to which the task of going to the bank makes sense of my ability to keep a tight rein on my accounts. Note, I stress the "me" to counter the rather implausible objection that this kind of perfunctory example need not involve any sense of "self", as though I were simply acting on autopilot. On the contrary, projecting a for the sake of which - a "reason" to do something - directly implicates $m e$ in some form of self-directed activity. In Heidegger's terms: a for the sake of which is always performed for the sake of myself.

The threat to Narrativity of this kind of anecdotal example, of which there is an infinite and abundant supply, is this: most people, in the main, go about their daily lives without any need to explicitly reflect upon who they are ${ }^{48}$; yet they are not, for that matter, lacking selves. Let us ask, then, are such selves, in any relevant sense, narrative? Naturally the answer to this will depend on what is to

\footnotetext{
${ }^{48}$ Recalling here that the high end Narrativity Thesis is not simply a descriptive but a normative thesis - and to the latter "making one's narrative explicit" is indeed a requirement.
} 
count as relevant in this context. If we take relevant, however, to imply NR and NS, then it is doubtful whether such a self could be narrative. Of course the narrativist might object that I am trying to discredit Narrativity on grounds Narrativity already has covered. J. David Velleman, for instance, tells us: "we tell many small, disconnected stories about ourselves - short episodes that do not get incorporated into our life-stories... Because the narratives of these minor episodes are never unified into a single story, their protagonist cannot derive his unity from theirs". ${ }^{49}$ The implication of this, I take it, is that the short episodes have their own specific kind of narrative unity that is independent of a person's life-story. ${ }^{50}$ It is the latter that unifies the person for it is the latter that provides her with a sense of "narrative coherence". ${ }^{51}$ The problem remains however: how do we account for these so called minor episodes that are so abundant, in fact ubiquitous? They have no significant narrative value because they do not contribute to my self conception; still less are they developmental. They are - to use Strawson's word - "saccadic": fragments that do not fit together like parts of a jigsaw puzzle to make up a coherent story. ${ }^{52}$. Yet these episodes are not the exception to the rule but constitute the very fabric of daily life. ${ }^{53}$ So the sense of relevant here becomes quite pertinent, for we must concede that averagely the self is perfectly coherent without paying heed to the Narrativity Requirement.

Consider a second, more general, problem for the narrativist. It has been pointed out that Narrativity is threatened by circularity (see Ricoeur 1990/1, Velleman 2006 ${ }^{54}$, and Christman 2004). Basically put: can Narrativity explain life if the concept of life already implies a connectedness of experience, that is, the kind of unity and meaning that we find in a narrative? Is not narrative already

\footnotetext{
${ }^{49}$ Velleman (2006, pp. 222-223).
}

${ }^{50}$ Even so, it is extremely dubious to say the least to ascribe to my depositing a cheque in the bank even the most minimal of 'story telling' activities; why should such perfunctory chores involve any narrative telling at all?

${ }^{51}$ Velleman (2006, pp. 219).

${ }^{52}$ Note however they do contra Strawson make a coherent picture of average intelligibility.

${ }^{53}$ As John Lippett has recently argued: "There is an important difference between asking whether particular aspects of a life hang together, and of whether a 'whole life' does, and the former experience is far more common that the latter" (Lippett, 2007, pp. 47-48).

${ }^{54}$ Velleman observes: "Narrative coherence cannot ultimately depend on rational justification if rational justification ultimately depends on narrative coherence” (Velleman, 2006, p. 219). 
tacitly assumed whenever we speak of a life? Perhaps it will be objected that this misses the point. The notion of "a life" is narrative, but only with respect to the person whose life it is; the real issue concerns self-constitution. Marya Schechtman writes, for instance: “An individual constitutes herself as a person by coming to organise her experience in a narrative self-conception". ${ }^{55} \mathrm{We}$ might ask, however: who, precisely, constitutes whom here? Since a person is supposed to be constituted through the act of self-narration (after all, that is the point of speaking of narrative self-constitution) then selfnarration cannot rely on the concept of the person, which it clearly presupposes, that is, if the person is just a self capable of connecting its experiences into a coherent story. Perhaps there is an easy rejoinder to be made here. Clearly Schechtman does not actually say that the person self-constitutes in the form of a narrative identity, it is the "individual" who does that. But this answer is ambiguous. Furthermore, it invites unwanted questions about the priority of the narrative account. Remember what Narrativity is trying to give an account of: what it is to be a person, a self. But it seems as if there is some more basic entity after all that is irreducible to a narrative self-conception, but which is required in order to save it from the charge of circularity. Consider, in this regard Velleman, who I think quite rightly analyses the notion of a narrative self-conception back to the notion of a "self-narrating agent" 56 - a self less identified with his story ("the autobiographer's reflective representation"57) than with an ability to self-interpret by way of that story. It is at this point, however, that I want to press Velleman further than he is willing to go: for why not say that narrative self conceptions can be analysed back to an ability to self-interpret?

In other words, Narrativity reverts to the more basic condition, I earlier called, "narratability". And narratability (the ability to self-interpret) does not automatically imply or involve or entail a narrative self-conception, for averagely we self-interpret in non-narrative ways - that is, without recourse to NR. ${ }^{58}$

\footnotetext{
${ }^{55}$ Schechtman (1996, p. 134).

${ }^{56}$ Velleman (2006, p. 221).

${ }^{57}$ Ibid., p. 220.

${ }^{58}$ Here I agree with John Christman’s assessment: “narrativity collapses into a capacity for selfinterpretation" Christman, 2004, 709 - my aim however is different from Christman's who does not really use this insight to get any leverage on the notion of the self. In that sense, Christman's analysis remains in principle "negative".
} 
Let me call weakened narrativity, "narratability", so as to distinguish it from high end Narrativity. More expressly stated narratability is the basic phenomenological condition for what I will call self-interpretative praxis. And narratability, I contend, is not the same thing as high-end Narrativity, for to distinguish narratability from Narrativity is first and foremost to point, not to the phenomenon of narrative per se, but to the general conditions on the possibility of any narrative-type activity as such. Moreover, phenomenologically interpreted, narratability provides the clue to a prenarrative phenomenon that is indicative of what it is to be a self. This indicative phenomenon narratability as pre-story-telling - might be better described as a "salience-conferring" ability. So, broadly taken, narratability conditions can be located, on the one hand, in our ability to find meaning in the world, and on the other hand, in the fact that this ability is prerequisite to the construction of anything like a sense of "narrative value". However, if this is right, then narratability should not entail the stricter requirements of narrative as a condition of selfhood - meaning-making per se does not impose NR, the Narrativity Requirement, any more than does the ability to self reference. Therefore, a phenomenological analysis of narratability conditions aims at a hermeneutic conception of the self as something prior to, and thus more fundamental than, the person (seen as the subject of a personal history.) Indeed, once phenomenologically interpreted, we shall see that the self is not narrative in form, but is the narratability condition par excellence.$^{59}$ In Heidegger's terms, the self is an ontological condition on the possibility of Dasein's factical interpretedness. ${ }^{60}$ Consequently, against those readings of Heidegger that emphasise narrative, specifically in their interpretation of Dasein's historicality, I recommend instead that we define historicality in the following terms: it is the basic activity that expresses Dasein's ability to "temporalise" itself by means of its involvement in a factical situation. To see that this is indeed plausible, let us examine in more detail the limiting case of an episode.

\footnotetext{
${ }^{59}$ Note, this does not mean that there are not other, perhaps "meta-phenomenological", narratability conditions, which are equally important in their own right. For instance, one might point to the work of Greimas in semiotics, which, although it is influenced by phenomenology, conducts its analysis at the higher level of socio-linguistics.

${ }^{60}$ Recall in the first division of Being and Time, Heidegger offers a minimal description of Dasein's ability to self reference (mineness or Jemeinigkeit) as constitutive of the ability of Dasein to self interpret.
} 


\section{Appropriating the Episodic View}

First, however, a caveat: If we are to make sense of an episode on Heideggerian grounds then we need to significantly qualify what we mean by the term. Now an episode, as Strawson has defined it, is a single unitary period of experience, which is also his stipulative definition of a self. Strawson's self, in fact, is a bare locus of experience: "a distinct, mental thing that is correctly said to be a subject of experience and a single thing within any hiatus-free period of experience". ${ }^{61}$ It is for this reason that he can endorse the basically Humean view that experience - that is, consciousness of one's self as presence-to-self, requires no longevity of the self. ${ }^{2}$ Quite the contrary: "Episodics, looking out from the present, have very little sense that the I that is a mental presence now was there in the past and will be there in the further future". ${ }^{63}$ According to what Strawson dubs the "Pearl view", the self appears to be elliptical, discontinuous, fragmentary, and essentially intervallic in form. In fact the Pearl View states that there are as many selves as there are identifiable phases of consciousness. ${ }^{64}$ Unlike the view

\footnotetext{
${ }^{61}$ Strawson $(2005 b$, p. 359.

${ }^{62}$ As Hume famously argued: “from what impression cou'd this idea be deriv'd?" Hume (1739, p.
} 164).

${ }^{63}$ Strawson (1999, p. 493).

${ }^{64}$ One temptation here would be to read into the Pearl View the kind of idea one finds in William James, and indeed there are similarities. James, in the Principles, at least, appears to reject the idea of a single self or "arch ego" which provides a bedrock of "metaphysical or absolute unity". Instead, he proposes the idea of a successive series of selves, which he identifies with successive appearances of "Thoughts". My present Thought is related to my past thoughts through family resemblance and sheer contiguity. His famous simile likens distant "selves" to cattle on a prairie, insofar as, bearing a brand, both form a herd: "there is found a self-brand, just as there is found a herd-brand" James (1981, p. 320). He also says this brand "runs through them all like a thread through a chaplet and makes them into a whole" ibid, p. 317. But it is precisely here that Strawson and James part company, for Strawson rejects the idea of a string: "many mental selves exist, one at a time and one after the other, like a (stringless) string of pearls... each is a distinct existence" Strawson (2005b, p. 359). And he says: "I think William James's famous metaphor of the stream of consciousness is inept” ibid., p. 356. Of course, James might well have had Strawson in mind when he spoke of the "great blunder" of Hume's view, which eliminates, as does Strawson, all sense of transitivity from the self (James, 1981, p. 237). 
of the Cartesian (for whom discrete spells of consciousness are taken as evidence of an underlying Cogito which persists through them), on Strawson's construal, there are as many Cogitos as there are Cogitationes. Now, let me briefly summarise my objection to Strawson's notion of an episodic self by saying (firstly) as I see it, what Strawson misses or fails to capture, despite describing his own project as "phenomenological", is precisely the phenomenological experience of the self. Bear in mind how he describes the self as a "single mental thing", something that is identifiable with any continuative or hiatus-free spell of self-consciousness, a "mental presence", and so on. But none of these descriptions leaves us any the wiser as to what makes a self specifically a self. A second objection has to do with the kind of temporality Strawson wants to impute to the self. Here, his claims are at best murky, at worst contradictory. Strawson's argument is that the self is basically non-diachronic; it is synchronic. ${ }^{65}$ If it is synchronic, however, this is not intended to suggest a purely punctualist theory of the self. Rather, the synchronic story Strawson wants to tell is more of an "at-the-time" account than an "at-aninstant" account. This, I take it, is meant to defuse an obvious ambiguity that arises with the punctualist theory which cannot really explain the unity of an experience. Strawson, at least, thinks an episode as having some temporal extension for he speaks of experience in terms of continuative spells of consciousness. Still, it is not entirely clear that Strawson evades incoherence in prioritising synchrony over diachrony. If the self has some duration, then we deserve a fuller account of what such duration comprises.

The net result of these two objections is that we need a more complex view of an episode if we are to bring the episodic self into view phenomenologically. Let me propose, then, an alternative way of thinking an episode, which does not involve a stipulative definition, but derives from a "thicker" phenomenology than Strawson's. In my view, an episode is akin to what - according to Heidegger's lexicon - we might refer to as an involvement. Consider the following example.

Jones is running in a marathon, raising money for a charity. On my recommendation, an involvement comprises a single unitary action: "the run". Thus it begins at the starting line and is completed when Jones crosses the finishing line. Because involvements are actional, they fall under transitive descriptions of the kind: "Jones is running the marathon in order to raise money for a charity". Note: the significance of the involvement will always be "thicker" than the action itself - that

\footnotetext{
65 "[The] basic form of our consciousness is that of a gappy series of eruptions of consciousness from a substrate of apparent non-consciousness" Strawson (1999, pp. 20-21).
} 
is, running the marathon. This is because involvements always make reference to that broader context of meanings in virtue of which they make sense. For instance, the privation of the run makes sense to Jones because it will raise charitable funds. We might say the race-episode makes sense in terms of the broader situation from which it receives its motivation. Involvements, in short, are situational, and situations comprise a nexus of interconnected activities whose meanings cut across one another. Notice, these activities need not be linearly connected: Jones might, for instance, train after work, or on weekends, fitting his schedule around his family and professional commitments as and when he can. Situations can be seen to consist of discrete segments of relatively autonomous activity with regard to other aspects of one's life. Moreover, every involvement constitutes a relatively closed period of activity - a single, whole, and meaningful action: running the marathon, mowing the lawn, going to the bank, attending a meeting. Regardless of this, there is no episode in which Jones is involved that does not derive its sense or meaning from some broader situational context that makes it an involvement worth his while doing. Involvements make sense in terms of Jones' situation which they in turn develop. Finally, if an episode can be defined in terms of an involvement then the duration of an episode is to be determined, not on cognitivist grounds, but agentially - by its pragmatic and actional significance, which will vary case-by-case.

Consider next two alternative approaches to my example. Call the first the Muybridge approach to action. For the Muybridge approach, which is kinesic, that the marathon constitutes an entire actional episode is quite irrelevant because it can be broken down into discrete segments of bodily activity. In fact, for the Muybridgean, involvements disappear altogether: Jones' marathon run consists of a series of independent mechanical states that can be cut out from the cloth of that involvement and described without reference to it. Let's call these "knees-legs-and-feet" episodes, because at any point in the race, the action of running can be viewed in terms of the physical movement of Jones' body. Notice, however, that while the action of running can be dissected into the physical movement of Jones' limbs, kinesic descriptions cannot make sense of the unity of his action, because they cannot make sense of the "in order to" integral to it ("running in the marathon in order to raise money for charity".) Take, now, a rather different, although in some senses, parallel view to the Muybridgean one.

As Jones runs the race he is conscious of many things - the blur of the road sweeping beneath his feet; the sounds of the crowd cheering the runners on; his resolve in the face of growing fatigue and 
weariness. At other times, however, Jones is not thinking of the race at all. And just as well because when he becomes explicitly conscious of the proprioceptive effects of running the task becomes impossibly onerous. Suppose that as Jones runs his mind drifts off in all directions, pursuing a myriad of fragmented, tangential, and episodic thoughts, each unconcerned with the task at hand. If we study Jones' mental life in this way what emerges is a picture of an episodic and elliptical consciousness consisting of a passage of fleeting thoughts, not one of which can make sense of Jones' action of running in the marathon. So who is able to make sense of this activity? Certainly not Jones' legs, feet, and knees because their movements are parasitic on and not explanatory of the reason for Jones' running. Could it perhaps be explicable by way of a string of disconnected selves, each briefly appearing for a moment before disappearing forever? I think that is rather unlikely, for one thing we have said none of them are invested in this activity at all. Thus both the Muybridgean view and the Strawsonian view confront the same fundamental dilemma: the phenomenon from which their own analysis derives becomes inexplicable on the terms they set out. In short, both approaches eliminate the intentional sense of the action. For that reason, neither can make any sense of it as an action. On my alternative view, by contrast, an episode encompasses the whole of an involvement because an involvement is itself definable as a single, unitary period of meaningful activity. It is meaningful only as a whole action, however, in connection with (a) the situation against which it is understood, and (b) insofar as it is meaningful for me - the intentional subject of the involvement.

At once, if this is right, an episode becomes much more complex than Strawson's phenomenology will allow. Correlatively, the "episodic" self is by no means reducible to an episode of consciousness, any more than a marathon is reducible to the mechanical motion of the runner's legs. Rather, the self is that phenomenon which is able to make sense of any period of involvement in which it features. It can do this because through its involvements it is disclosive of its broader situation in terms of which things matter to it.

\section{Narratability as Self-interpretative Praxis}

Still, it might be objected that by locating such actional episodes within their broader situational contexts I have covertly relied on the very thing I seek to exclude. To show, then, that narratability is indeed distinct from narrativity I want to consider more closely the relation of an episodic, actional self to its practical situation. Take a further example. Say you have found a hole in the sole of your 
favourite pair of shoes. You take the shoes to your local heel bar and give them to Smith, the shoe repairer, who sets to work resoling the shoes for you. As you wait you casually glance around the heel bar, noticing all sorts of paraphernalia that strike you as odd: the rotary cutters and abrasive wheels, the pneumatic presses, the various stapling tools, and so forth - all of which you recognise as tools, yet without any sense of their purpose. For Smith by contrast the "what-for" of the equipment is so obvious he barely thinks explicitly of it at all. The situation, the equipmental environment (the world of the heel bar) is perfectly intelligible to him; it is his world and he is quite at home in it. How does this largely unremarkable background manifest itself? Well, just in his ability to make suitable use of this equipmental environment in order to repair shoes. Resoling your shoe, however, is not just a task for him - it is of course $a$ task, but it is also more - it is fundamentally expressive of a way of being for him. It is expressive of Smith's ability-to-be. Who he is - who he takes himself to be - is fully operative in the task of repairing your shoe. He mends the shoe for the sake of his ability to be a shoe repairer; and by pressing into that ability, Smith is for the sake of some determinate possibility of himself.

Perhaps this will raise the hackles of the narrativist, who will complain, no doubt, that still the phenomenology is too thin. Doesn't this also lead to a reductive account of the self - to a reduction of Smith's who? Surely, Smith is more than his ability to repair shoes? Maybe he is also a family man; someone with a passion for poetry, or a committed supporter of his local football team. Moreover, the reason why he is all of these things can only be explained by looking to his past - to his personal history. For instance, perhaps Smith is an avid reader of poetry because a particular schoolteacher, seeing talent in him, encouraged him to read Yeats or Pound. But notice, while this may well be the case, nothing here necessitates either NR or NS. That Smith's past shows up in a variety of ways in his present does not, in itself, involve him in a narrative self-conception, nor need his past be made explicit to him in order for Smith to self-interpret in the various ways he does. Facts about someone's past, even though they may well explain their current preferences, or why they conceive themselves in one way and not another, do not of themselves explain what it is to be a self; nor for that matter do they make someone "narrative". To this reproach, then, we can indeed concede, yes Smith may well be "all of the above", although never all of the time. The point at issue is phenomenological and not characterlogical; it concerns how Smith's "who" discloses itself through his pragmatic involvements. So, even though it is true that in the moment of repairing a shoe, Smith is not everything that he might 
be - a family man, an angler, a football supporter, etc - he is, nevertheless, everything he 'is' in that moment of commitment. And he is so just to the extent that in that involvement he is for-the-sake-of his particular chosen ability-to-be.

But perhaps the narrativist will insist on his objection - that Smith really is also a family man, for that is how he sees himself. Indeed, if one were to ask him, no doubt he would say that he repairs shoes to support his family. But again, I think this objection misses the mark. By pressing into repairing shoes, we can indeed accept that Smith's "being-for-the-sake of his family" is also expressed. ${ }^{66}$ Nevertheless, at that moment of pragmatic involvement, Smith's being-for-the-sake-of mending the shoe is superordinate to his being a family man. The task of mending a shoe involves no narrative meaning, then. Nor, in point of fact, does being a family man require Smith to narrate himself as a family man, notwithstanding the fact that on occasion he could do so. ${ }^{67} \mathrm{He} i$ s a family man, not because he thinks of himself that way, but primarily because he is able to press into whatever involvements his particular familial situation demands of him. Notice, then: in order to be Smith, all that is required on Smith's part is that he respond appropriately to the different situational contexts in which he habitually features, for it is these that allow Smith to make sense of his ability-to-be. Notice, also, none of these interpretative contexts, or so I contend, implies, and still less, obliges us to accept NR and NS. Smith does not need Narrativity in order to make sense of himself, his projects, or his commitments.

Finally, to demonstrate that there is a real problem for Narrativity at this point, we need merely turn the narrativist question back on itself: for if the answer to who Smith is cannot be assessed without recourse to his "whole" history, and if that history is self-evidently not present in the task of repairing a shoe then, in that case, Smith could never be a self, since at no point could any possible

\footnotetext{
${ }^{66}$ See Heidegger, 1962, p. 116.

${ }^{67}$ Smith may very well describe himself as a family man in, say, the context of a job interview, if asked; narratability does not deny that narrative self-conceptions are possible. It says they are not fundamental. Smith's ability to form a narrative self-conception does mean that being a family man signifies anything like a state characteristic that can define the essence of his "who". Smith's being a family man does not derive from his self-ascribing such a property to himself; it derives from the way he understands himself, and that understanding is largely rooted in his comportmental behaviour - it is primarily pragmatic; that is, it is not a "telling" but a "doing".
} 
involvement meet that strict requirement. On the other hand, it would be peculiar to say that when mending shoes Smith was not wholly present; what, after all, would it mean to speak of his partial presence? Is Smith's self scattered across a range of situations such that it could never be whole at any given time? Smith himself would surely think that rather doubtful. So how are we to explain this phenomenological ambiguity, namely, that the self is wholly present in its episodic involvements, but that these involvements do not amount to everything that this self could be?

Well, in my view, the self is wholly given in and with its involvements - yet is not identical with them. Rather, it is operational through them. In this view, the self is not a thing, as Strawson conceives it, but equally nor is it strictly a "someone" with an 'identity' as the narrativist would have it. "Selfhood" describes, rather, a mode of being. For Heidegger, it is that mode of being belonging to Dasein, which - in the temporalisation of temporality - is self-presenting. In this fashion, Dasein generates its world. This, on my reading, is the fundamental import of the thesis of historicality: it describes the process of temporalisation in a concrete and pragmatic context - for "historicality" is, as Heidegger remarks, at one point, "at bottom, just a more concrete working out of temporality" ${ }^{68}$ Specifically: Dasein temporalises itself by projecting itself onto a future whose possibilities are conditioned by its having already been determinately disclosed (thrown). So - to return to our example: in going into the heel bar every morning, Smith returns to an equipmental situation that he is already familiar with. From that "retained" situational context he understands that for which he works when repairing shoes. Existing between this retentional context of equipment and protentional "for the purpose" of mending shoes, Smith "stretches" his present as a time of pragmatic involvement. ${ }^{69}$ In this, and no doubt in a manifold of innumerable other ways, "Smith happens".

The significance of this rendering of the self, if right, can be expressed now as follows. In the minimal case of average Dasein, we find (1) an operative, self-comporting mode of being that understands itself through its episodic involvements. Since these are largely inchoative (2) NS is not implied. And since they are episodic (3) there is no Narrativity Requirement (NR) either. On the other hand, we find a thicker temporal framework for an episodic involvement than in Strawson (4). To this we may add the following supplementary observations. In saying that the self is a mode of being, Heidegger is offering an ontological determination of the self independent of any factical identity it

\footnotetext{
${ }^{68}$ Heidegger (1962, p. 434).

${ }^{69}$ For a lucid account of pragmatic temporality, see Blattner 1999.
} 
may have. Ontologically grasped, the self is explanatory of the phenomenon of involved being-in-theworld prior to any personalistic psychology of the self. In fact, Heidegger's aim is to disclose that categorial structure that makes any factical self-comportment - "mineness" (Jemeinigkeit) - possible: "[Being] toward oneself as Being a self," says Heidegger at one point, "is the presupposition for the various possibilities of ontic relations to oneself'. ${ }^{70}$ Understood in this way, the self is not narrative; to repeat: it is a narratability condition. The self refers to a mode of being whose defining feature is that it is self-interpreting. And because self-interpretation should not be confused with self-narration, narratability does not require that Dasein should be self-authoring in order for it to be a self. Dasein interprets itself averagely by involving itself in a world whose significance has been pre-understood. For this reason, what I have conceived here as the condition of narratability (Dasein's ability to selfinterpret by means of its situation) does not preclude the obvious fact that for the most part - and precisely because it is average - Dasein's who is "always already" interpellated by its "world" and by its "being-with-others".

Now, to be sure, it is open at this point to the narrativist to concede that average Dasein indeed interprets itself by means of "das Manish" gestalts - but das Man is certainly not in possession of its self and that is precisely the point at issue in Narrativity. What Heidegger has in mind when speaking of authentic historicality, recalling the final configuration view, is this: that authentic resolve requires I take responsibility for my life as a whole. Authenticity entails the Narrativity Requirement because it involves NS - getting clear about myself. ${ }^{71}$ To suggest an alternative to this scenario, and thus meet this objection, I want to offer one final example, this time taken from Terrence Malick's film The Thin Red Line. The fact that this derives from a "narrative" film does not impugn the phenomenological point - on the contrary, it makes the point, by offering a plausible alternative to the idea that authenticity necessarily involves Heidegger's endorsement of NR. The idea I want to advance here is that being a strongly narrative person provides no guarantee against viciousness and venality; while, in contrast, the episodic self provides an equally plausible paradigm for an authentic self. We should also

\footnotetext{
${ }^{70}$ Heidegger, ([SS] 1928, p. 189).

${ }^{71}$ Note, the Narrativist insists that getting clear about myself requires getting clear about my narrative. Apart from the circularity of this claim, one can also challenge the idea that getting clear about myself involves self-narration at all - something I have examined elsewhere in relation to Heidegger's use of the notion of conscience.
} 
take note, at this point, that the underlying issue in dispute - historicality conceived as a narrative structure - must regress, finally, to the question of how Heidegger construes of ones "past" as showing up in ones "present". So, on the one hand, there is the narrative interpretation of "having been", which I contend implies a psychologising of Heidegger's construal of the past - this is particularly evident in Guignon's reading of authenticity, where psychological connectedness is applied to authentic historicality. On the other hand - if we are to indeed conceive of a non-narrative (and thus nonpsychological) way of accounting for the idea of authentic historicality, then we must show how determinate "having been" can inform one's present circumstance without invoking the narrativity requirement.

The example, then, concerns a contrast between two of the film's principal characters: Lt. Col. Gordan Tall (played by Nick Nolte) and Private Witt (played by Jim Caviezel). The situation of these two men is the barbaric and bloody struggle between the Japanese and American forces for Guadalcanal in the Western Pacific during the Second World War. What is significant is how both men understand and interpret that situation in radically different ways. I would like to propose that one of them understands the situation in Narrativist terms (Tall) while the other understands it in more Episodic terms (Witt). Colonel Tall, in fact, at one point expressly voices his narrative interpretation of the situation by proclaiming: "I've waited all my life for this. I've worked, slaved, eaten buckets of shit to have this opportunity and I don't intend to give up now". Observe that it is Tall who thereby fulfils the requirements of full Narrativity - for he sees the present situation specifically in terms of his life-gestalt (his "story"). He makes sense of his situation by resolving upon a determinate selfconception in which that situation becomes narrativised. Let's say that Tall in this manner meets the main requirements of Narrativity. Tall comes to constitute the tragi-heroic focal point of the situation; he sees himself as its principal dramatis persona. It could be argued, of course, that in this way he has indeed authentically resolved on the situation for it is he who knows what needs to be accomplished in order to win the battle. The fact that he pursues this goal ruthlessly, with callous disregard for the lives of his men is quite beside the point.

In contrast, Witt does not know how to send men to their deaths, but he does know how to help them face death - and it is he who finally faces up to death. What, however, is most notable - and this is the principal point I want to make here - is that Witt does not attempt to make sense of his situation in terms of his life-story. Rather, he effects what we might call a "hermeneutic inversion" of 
the Narrativity Thesis. He does not appropriate the situation to his life by projecting a life-gestalt in order to make sense of it. On the contrary, he allows his life to be appropriated for the sake of the situation. That is to say, how Witt makes sense of the current situation is not by casting it as part of his ongoing life-story (the narrative or final configuration view) but by drawing on his life as a narratable resource. In Witt's case, "life" is not the narrative he tells about himself - what it provides, on the contrary, is the experiential basis for a non-narrative hermeneutic understanding through which he is able to interpret the current situation in a non-identitarian and non-subsumptive way. ${ }^{72}$ Specifically, he is not driven to act according to the dictates of his narrative self-conception; rather, he exists for the sake of the situation itself. If this is right, then it is not the narrativist Tall, after all, but the episodic Witt whose stance is best described as resolute openness to what matters in the present moment. Of course, it may also be that Tall's life-gestalt is all wrong; that his self-conception is corrupted by inauthentic military dogma; and because of this he fails to interpret the situation genuinely. Perhaps there are authentic and inauthentic forms of Narrativity. But even if this is correct, I doubt whether the high-end Narrativist could find any solace here. After all, in that case the Narrativity Requirement by itself could not assure us of the ethicality or authenticity of our (narrative) self-conceptions (assuming for the sake of discussion that authenticity implies an ethico-juridical conception of the self).

\section{Conclusion}

I began by outlining in some detail two opposed camps within the Heidegger literature on the issue of narrativity, which I designated the "final configuration" view and the "unattainability" view. I argued that both positions have their merits and drawbacks. The unattainability view rightly shows Dasein's ontology to be incommensurable with expressivism but neglects the thesis of historicality; the final configuration view sees the importance of historicality but overinflates it in ascribing to authenticity NR and NS as basic criteria. I suggested an alternative thesis to Narrativism - that of narratability - as a way of understanding the notion of historicality without narrativity. The aim of this suggestion, recall, was not to resolve these two interpretations of Heidegger. On the contrary, it is to show that the exegetic tension between final configuration and unattainability itself hints at something important about what it means to exist as Dasein. Narratability, I believe, allows us to make this tension explicit.

\footnotetext{
${ }^{72}$ Witt, for example, knows what it is to suffer and to die because he has already witnessed the agonising death of his mother.
} 
For, on the one hand, Narratability accepts the fact of narrativity: that we are at times tempted to ascribe narrative value to our lives. And yet narratability also acknowledges that narrativity plays an ambiguous role in the project of existing, since it exposes the far deeper ambiguity of Dasein's existential situation. The ambiguity can be most explicitly stated in the form of a paradox. Human temporality generates the possibility of factical life and at the same time undermines what appears to be most intrinsic to it. That is to say, the profound impetus within life to realize itself in some meaningful whole (to which final configuration rightly responds), in fact arises from out of the very nullity of existence which (according to the insights of unattainability) prohibits its accomplishment.

In this sense, what we might call the narrativist question par excellence - the Homeric question that leads the tragic hero to dream of a "return to Ithaca" - and which, rather more mundanely, compels me, in moments of anxiety, crisis, or grave doubt, to ask myself "who am I?" Who ought I to be? - is indeed perfectly legitimate within limits. What the existential analysis of narratability conditions reveals however is precisely in what way those limits are to be understood. Specifically, they show that no answer to this question can ever prove sufficient for a being such as Dasein. Narratability, applied to this kind of authentic self-insight, confirms instead two fundamental truths about Dasein. First, that the task of living requires that one keep the question of who one is genuinely open; and, second, that those who seek a "complete meaning" in the wholeness and unity of a life, do so in vain. Narratability reveals, in other words, that the phenomenon which Heidegger designates as Dasein's "self" is ultimately irreducible to the set of beliefs, values, and norms that make up the story it self-ascribes when defining itself as a "someone".

Bibliography

Atkins, Kim. 2004. Narrative Identity, Practical Identity and Ethical Subjectivity. Continental Philosophy Review, 34: 341-366.

Blattner, William. 1999. Heidegger's Temporal Idealism. Cambridge: Cambridge University Press.

Carman, Taylor. 2003. Heidegger's Analytic, Interpretation, Discourse, and Authenticity in Being and Time. Cambridge: Cambridge University Press.

Carr, David. 1991. Time, Narrative, and History. Indianapolis: Indiana University Press.

Christman, John. 2004. Narrative Unity as a Condition of Personhood. Metaphilosophy 35, No. 5, October.

Dennett, Daniel. 1992. The Self as the Centre of Narrative Gravity. In Self and Consciousness: Multiple Perspectives. New Jersey: Lawrence Erlbaum Associates Inc.

Dreyfus, Hubert L.. 2001. Being in the World, A Commentary on Heidegger's Being and Time, Division 1. Cambridge, Massachusetts, London: The MIT Press.

Guignon, Charles. 1983. Heidegger and the Problem of Knowledge. Indiana: Hackett Publishing Company.

Guignon, Charles. 1992. History and Commitment in Early Heidegger. In Heidegger, A Critical Reader, eds. Hubert Dreyfus and Harrison Hall. Oxford: Blackwell Publishing. 
Guignon, Charles. 1993. Authenticity, Moral Values, and Psychotherapy. In Cambridge Companion to Heidegger, ed. Charles Guignon. Cambridge: Cambridge University Press.

Guignon, Charles. 2000. Philosophy and Authenticity: Heidegger's Search for a Ground for Philosophizing. In Heidegger, Authenticity, and Modernity, Essays in Honor of Hubert L.

Dreyfus, vol.1, eds., Mark Wrathall and Jeff Malpas. Cambridge Massachusetts: The MIT Press.

Guignon, Charles. 2004. On Being Authentic. London and New York: Routledge.

Heidegger, Martin. 1927 (2001). Sein und Zeit. Tübingen: Max Niemeyer - in text SZ.

Heidegger, Martin. 1962. Being and Time, trans., John Macquarrie and Edward Robinson (New York: Harper \& Row.

Heidegger, Martin. [SS] 1927 (1988). The Basic Problems of Phenomenology. Trans. Albert Hofstadter. Bloomington \& Indianapolis: Indiana University Press.

Heidegger, Martin. [SS] 1928 (1992). The Metaphysical Foundations of Logic. Trans. Michael Heim. Bloomington and Indianapolis: Indiana University Press.

Heidegger, Martin. 1929/30 (1995). Fundamental Concepts of Metaphysics, World, Finitude, Solitude. Trans. By William McNeill and Nicholas Walker. Bloomington and Indianapolis: Indiana University Press.

Hume, David. 1793. A Treatise of Human Nature. David Fate Norton and Mary J. Norton (Eds). Oxford: Oxford University Press.

James, William. 1981. The Principles of Psychology, Volume 1. Cambridge, Massachusetts and London: Harvard University Press.

Kisiel, Theodore. 1995. The Genesis of Being and Time. Berkeley: University of California Press. Lamarque, Peter. 2004. On Not Expecting Too Much from Narrative. Mind \& Language 19, No. 4, September, 393-408.

Lippett, John. 2007. Getting the Story Straight: Kierkegaard, MacIntyre and Some Problems with Narrative. Inquiry 50, No. 1, (Feb).

Parfit, Derek. 1987. Reasons and Persons. Oxford: Clarendon Press.

Ricoeur, Paul. 1990/1. Time and Narrative, vol. 1. Translated by Kathleen McLaughlin and David Pellauer. Chicago and London: The University of Chicago Press.

Sartre, Jean-Paul. 2008. Existentialism \& Humanism. Translated by Philip Mairet. London: Methuen.

Schechtman, Marya. 1996. The Constitution of Selves. Ithaca and London: Cornell University Press.

Schechtman, Marya. 2005. Empathic Access: the Missing Ingredient in Personal Identity. Personal Identity. Raymond Martin and John Barresi (Eds). Oxford: Blackwell Publishing.

Strawson, Galen. 2005 a. Against Narrative. The Self? Oxford: Blackwell Publishing Ltd.

Strawson, Galen. 2005 b. The Self. Personal Identity. Raymond Martin and John Barresi (Eds). Oxford: Blackwell Publishing; and 1999. Models of the Self. Shaun Gallagher and Jonathan Shear (Eds). San Diego: Imprint Academic, University of California.

Taylor, Charles. 2002. The Sources of the Self, the Making of the Modern Identity. Cambridge: Cambridge University Press.

Taylor, Charles. 1976. Responsibility for Self. The Identities of Persons. Amélie Oksenberg Rorty (Ed). Berkeley, Los Angeles, London: University of California Press.

Velleman, J.David. 2006. The Self as Narrator. Self to Self, selected essays. New York: Cambridge University Press. 